Sri Lanka J. Aquat. Sci. 12 (2007): 103-114

\title{
Substrate characteristics and species diversity of marine angiosperms in a micro-tidal basin estuary on the west coast of Sri Lanka
}

\author{
K. H. W. L. DE SILV A AND M. D. AMARASINGHE* \\ Department of Botany, University of Kelaniya, Sri Lanka. \\ *Corresponding author (E-mail: mala@kln.ac.lk)
}

\begin{abstract}
Diversity of marine angiosperm species (seagrasses) at Kadolkele in Meegamuwa (Negombo) estuary was studied with a view to understanding the effect of substrate characteristics on diversity. Seagrass samples were obtained along three line transects, laid perpendicular to the shoreline at $20 \mathrm{~m}$ intervals. Shannon-Wiener index was used to determine the species diversity of seagrasses in the study site at Kadolkele that was divided into three strata, demarcated by the distance, i.e. $0-10 \mathrm{~m}, 10-20 \mathrm{~m}$ and $20-30 \mathrm{~m}$ from the shoreline. Comparison of Shannon-Wiener index values indicated that the diversity of first stratum close to the shoreline was significantly different from that of the other two among which no significant difference was found to occur. Substrate $\mathrm{pH}$, soil electrical conductivity, organic mater content and particle size distribution were measured from the substrate samples taken from each stratum. No statistically significant difference was observed with $\mathrm{pH}$ (3.92-6.82) and particle size distribution among the three strata. Soil electrical conductivity and organic matter content of stratum 3 however, was significantly different $(\mathrm{p}<0.05)$ from the other two strata. Kadolkele seagrass bed consisted of two species and Halodule pinifolia (5822 shoots $\mathrm{m}^{-2}$ ) dominated over Halophila ovalis (1030 shoots $\left.\mathrm{m}^{-2}\right)$. The area adjacent (0-3 $\mathrm{m})$ to the mangroves at the shoreline was devoid of seagrasses and $H$. ovalis was absent in stratum 1, indicating that substrate characteristics have a marginal effect on the species richness of the seagrasses. Although species richness was similar in the other two strata, higher (Shannon) evenness (0.231), despite the relatively low abundance in stratum 2 , contributes to its higher species diversity. Present study therefore documents the subtle habitat partitioning of co-existing marine angiosperm species in a limited area in Meegamuwa estuary.
\end{abstract}




\section{Introduction}

The marine angiosperms in general are termed seagrasses due their grass-like habit and as they are found either in coastal or marine environments where they are considered to have evolved (Abeywickrema and Arulgnanam 1991). They are reported to play a significant ecological role in the functioning of near-shore coastal ecosystems, including lagoons, estuaries and shallow continental shelf waters (Fourqurean et al 2001). The "true seagrasses" are submerged monocotyledonous angiosperms belonging to 2 families (Hydrocharitaceae and Potamogetonaceae) 12 genera and 49 species (Den Hartog 1970). They are adapted to the marine environment and complete their life cycle under water, thus having a hydrophiloupollination (Aber 1920; Odum 1959). Accordingly, Zostera, Phyllospadix, Heterozostera, Posidonia, Halodule, Cymodocea, Syringodium, Thalassodendron, Amphibolis, Enhalus, Thalassia, and Halophila are considered "true seagrasses" while genera such as Zannichellia, Lepilaena, Althenia, Ruppia, Najas marina, N. graminae and some species of Potomogeton that fulfill the above criteria, nevertheless are found to occur in a wide range of salinities are excluded from the group (Takhtajan 1969).

Seagrass ecosystems that occur in tropical and subtropical shallow marine waters are ranked high amongst the Earth's most productive ecosystems and therefore serve as a source of energy for complex food webs in shallow coastal waters (Duarte 1991). They have also been proven to contribute to provision of habitats for aquatic organisms, including epiphytes, to consolidate sediment (Fonseca, 1989) and to produce detritus (Walker and McComb 1992, Alphonse and Winemiller 1997) for the aquatic food webs in these waters. They also serve a nursery function for a large number of fish and crustaceans that take these ecosystems as refuge, particularly the early stages of their life cycles that are vulnerable for environmental changes and predation (Al-rousan et al 2005; Johnson and Johnston 1995).

Among the factors controlling distribution of seagrasses in shallow coastal environments, light, temperature and nutrients are considered crucial (Dumbaald and Wyllie 2003). Besides, the substrate characteristics are logical to be envisaged to have a bearing on structure and hence function of these sub-tidal ecosystems. Sheltered zones with a substratum consisting of sand, mud, and dead coral seem to be ideal for higher seagrass cover and high species richness. Some species have been observed to grow best in certain substrata, for example, Enhalus acoroides and Thalassia hemprichii have shown better morphological features (long thick lamina, robust rhizome) in muddy substrata but can also form dense meadows in sandy substrata with mud. (Hans 1996).

Compared to other coastal ecosystems, scanty information, that is restricted to species composition is available for seagrass ecosystems in Sri Lanka. A total of 15 species belonging to nine genera have hitherto been reported from Sri Lanka (De Silva and Ranathunga 1987; Abeywickrema and Arulgnanam 1991; Jayasuriya 1991; Dayaratne et al. 1997; Amarasinghe et 
al. 2003). One fifth of the 3,200 ha of Meegamuwa (Negombo) estuary is covered with seagrasses (De Silva and Ranathunga, 1987). Four major angiosperm genera and seven species, i.e. Halophila beccarii, $H$ minor, $H$. ovalis, Thalassia hemprichii, Potemogeton pectinalis, Halodule pinifolia and Ruppia maritime, out of which four are true seagrasses, have been reported to occur in Meegamuwa estuary (Jayasuriya 1991; Amarasinghe et al 2003).

Seagrasses, being plants occupying sub-tidal habitats, have shown to be sensitive to turbidity and siltation (Gamp et al. 2003). It has been estimated that out of the 200,000 tonnes of sediment that reach this Meegamuwa estuary annually, approximately 50,000 tonnes are deposited in it yearly (Samarakoon and van Zon 1991). Declining shrimp and finfish catches are often attributed to declining estuarine areas with sufficient depth due to siltation (Samarakoon and van Zon 1991). In this backdrop, substrate characteristics of the seagrass bed at Kadolkelle was studied with a view to understanding its potential effect on marine angiosperm diversity in the area.

\section{Materials and Methods}

\section{Study area}

Meegamuwa estuary is located on the west coast of Sri Lanka and it extends over 3200 ha. Attanagalu oya/ Dandugam oya with a basin that covers approximately $934 \mathrm{~km}^{2}$ drain into this estuary. Meegamuwa estuary is one among the 45 major coastal water bodies in Sri Lanka and its average depth is approximately $1 \mathrm{~m}$ and the maximum depth is $6 \mathrm{~m}$ that occurs in the channels. A micro-tidal regime exists around Sri Lanka and the tidal amplitude during most of the year is less than $50 \mathrm{~cm}$.

\section{Study site}

The present study was carried out at Kadolkele area in the north eastern part of the Meegamuwa estuary (Figure 1) during the period, May to September in 2003. Seagrass bed at Kadolkelle is bordered by a mangrove area in which Rhizophora mucronata dominates the water-front edge Auxiliary information and personal observations made on the distribution of seagrasses from the shoreline towards deeper parts of water indicated the presence of gradients. In order to eliminate the effect of salinity on seagrass diversity,

\section{Sampling method}

Three substrate/soil samples were taken from each vegetation sampling point and they were pooled to obtain a composite sample. Thus, 36 composite soil samples were obtained from the three strata. Soil $\mathrm{pH}$ and conductivity (Eigenberg et al. 2002) measurements were obtained. Soil organic matter content was determined by measuring the loss of weight of soil samples dried and ignited at $400^{\circ} \mathrm{C}$ for $24 \mathrm{hrs}$. Soil particle size fractions were obtained by sieving a sample of ash-free soil (without organic matter). W eight of the separated fractions of soil particles, using a mechanical sieve with mesh sizes, $2.5 \mathrm{~mm}, 1.0 \mathrm{~mm}$ and $0.5 \mathrm{~mm}$ in diameter was measured. 


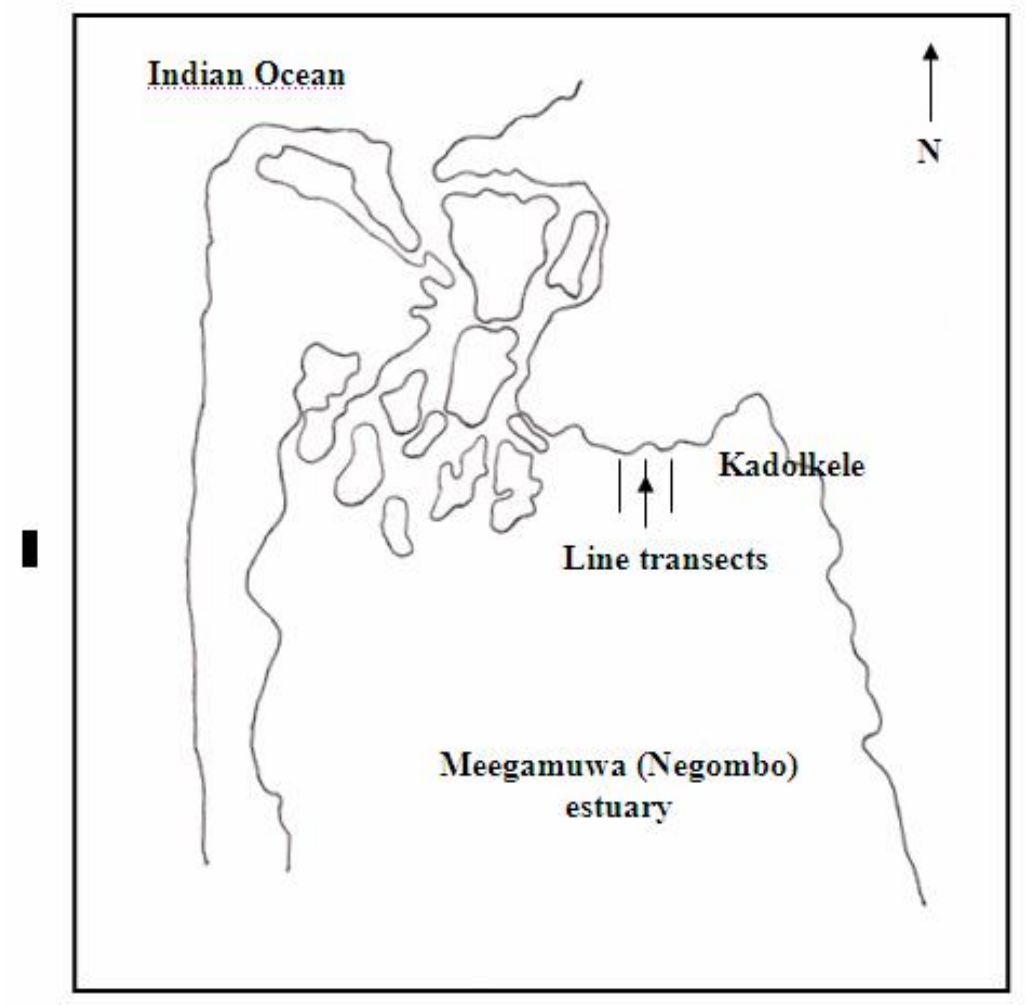

Figure 1. Location of study site and transects of Kadolkelle area where the salinity of water varies around $25 \mathrm{ppt}\left(\mathrm{g} \mathrm{L}^{-1}\right)$ was selected as the sampling area.

Seagrass samples were taken along $30 \mathrm{~m}$ long line transects laid perpendicular to the shore line at $20 \mathrm{~m}$ intervals. Based on the cursory observations on the distribution of seagrasses, the area delineated by $10 \mathrm{~m}$ intervals from the shoreline were arbitrarily considered as separate spatial strata and four seagrass samples each from the three strata i.e. $0-10 \mathrm{~m}, 10-20$ $\mathrm{m}$, and 20-30 m from the shoreline, were obtained using a $25 \mathrm{~cm} \times 25 \mathrm{~cm}$ quadrate. Seagrasses were removed along with the sediment attached to the rhizomes and roots and subsequently they were removed by sieving and washing in the estuarine waters. A total of 36 seagrass samples were taken from the area. A shoot (a growing tip) was considered as an individual plant. Species abundance was calculated by counting the number of shoots of seagrass species encountered in the 36 quadrate samples. Species diversity was computed using Shannon-Wiener index and the student t-test was used to compare that of the three strata (Brower et al 1997). 


\section{Data analysis}

All substrate parameters measured were compared among the three strata, using one-way ANOV A. Shannon-W einer diversity index (equation I) values among the three strata were compared using the Student t- values calculated using the equation II.

$$
\left.\mathrm{H}^{\prime}=-\sum \mathrm{p}_{\mathrm{i}} \log \mathrm{p}_{\mathrm{i}} \quad \text { (Equation } \mathrm{I}\right)
$$

$\mathrm{H}^{\prime}$ is the diversity index and $\mathrm{p}$ is proportionate abundance of species.

Student's t value $=\mathrm{H}_{1}^{1}-\mathrm{H}_{2}{ }_{2} / \sqrt{\mathrm{S}^{2}}{ }_{1}+\mathrm{S}_{2}{ }_{2} \quad$ (Equation II)

(Brower et al. 1997)

$\mathrm{H}^{1}{ }_{1}$ and $\mathrm{H}^{1}{ }_{2}$ are the diversity indices of the two strata while $\mathrm{S}$ and $\mathrm{S}_{2}$ are the corresponding standard deviations.

Linear regression analyses were performed to discern the relationship between substrate characteristics and marine angiosperm abundance (density), evenness and diversity.

\section{Results}

\section{Substrate characteristics}

Sediment $\mathrm{pH}$ and particle size distribution (sand and silt contents) did not show a statistically significant difference among the three strata (Figure 2). Nevertheless, stratum 3 was significantly different $(\mathrm{p}<0.05)$ from the other two strata with respect to organic matter content and soil electrical conductivity while stratum 1 and 2 were homogenous in this respect (Figure 3).

\section{Marine angiosperm diversity}

Two marine angiosperm species, i.e. Halodule pinifolia (Family: Potamogetonaceae) and Halophila ovalis (Family: Hydrocharitaceae) were encountered in the seagrass bed at Kadolkele.H. pinifolia (5822 shoots $\mathrm{m}^{-2}$ ) was more abundant than $H$. ovalis $\left(1030\right.$ shoots $\left.\mathrm{m}^{-2}\right)$. Density of marine angiosperms in stratum 1 was significantly lower than that of the other two strata, as 0-3 $\mathrm{m}$ zone from the shoreline was devoid of plants. Density in stratum 3 was greater than that of stratum 2 (Figure 4) and the difference was statistically significant $(\mathrm{p}<0.05)$.

Since there was only one seagrass species found to occur in stratum 1 , the evenness and Shannon-Weiner index values for stratum 1 was zero. The evenness for stratum $2(0.231)$ was greater than that of stratum 3 $(0.1325)$ and the diversity of stratum 2 also was greater $(0.74)$ than that of stratum 3 (0.54). A statistically significant relationship exists between evenness and species diversity in the study area $(r=0.9836)$. Comparison made using Student's t-values revealed that diversity of stratum 1 is significantly different from the other two strata while that exists between stratum 2 and 3 is not statistically significant. 
(a)

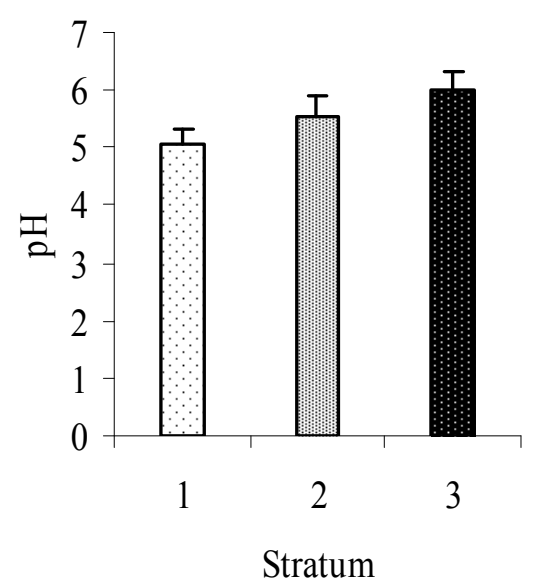

(b)

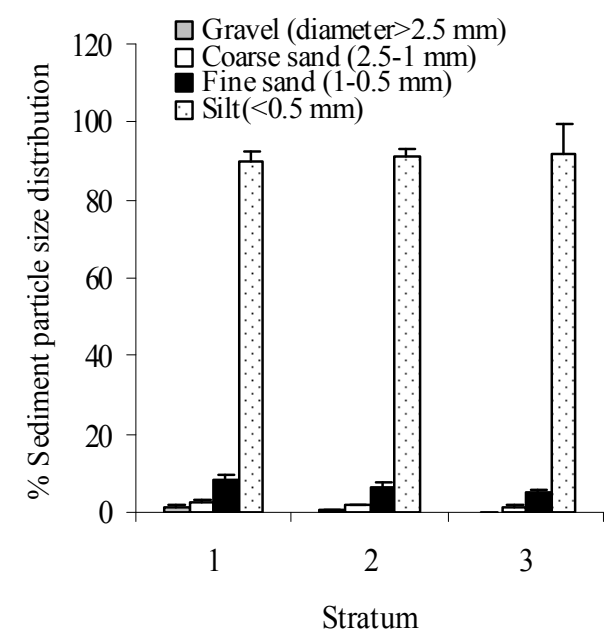

Figure 2. $\mathrm{pH}$ (a) and particle size distribution of soils (b) in the seagrass teds of Kadolkele. (Each histogram represents the mean of 12 replicates $\pm \mathrm{SE}$ )

(a)

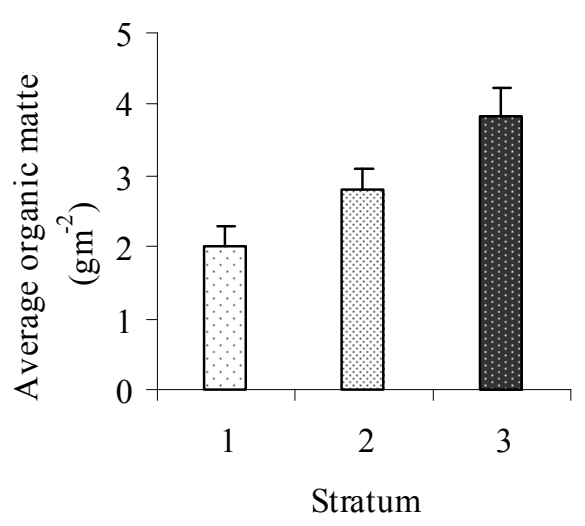

(b)

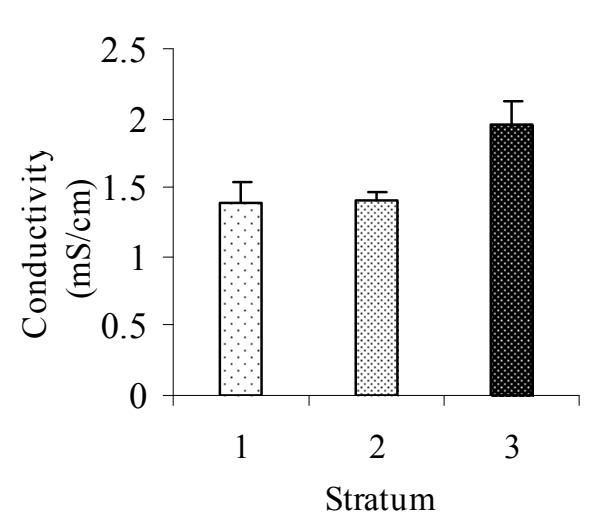

Figure 3. Average organic matter content (a) soil electrical conductivity (b) in the thre strata at Kadolkelle. (Each histogram represents the mean of 12 replicates \pm SE) 
(a)

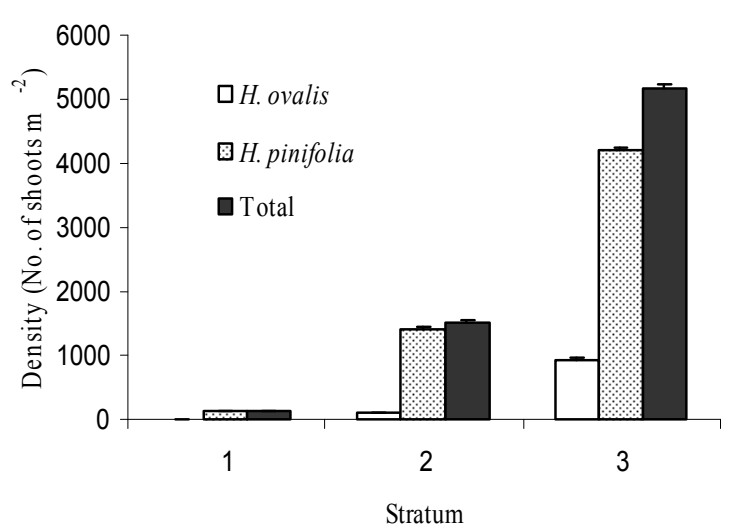

(b)

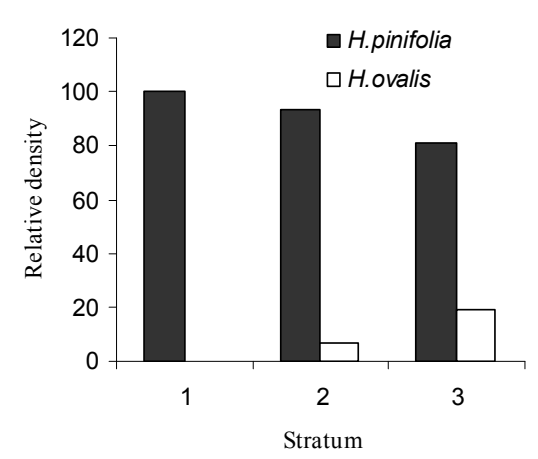

Figure 4. (a) Density of all seagrass species of the two constituent species (b) relative density of the two species in the three strata $(1-0-10 \mathrm{~m} ; 2-10-20$ $\mathrm{m} ; 3-20-30 \mathrm{~m}$ ) at Kadolkelle. (Each histogram represents the mean of 12 replicates $\pm \mathrm{SE}$ )

A statistically significant relationship ( $p>0.01)$ was found to exist between organic matter content and total seagrass density (Figure 5) as well as density of $H$. pinifolia at Kadolkele (Figure 6).

\section{Discussion}

\section{Substrate characteristics}

Analyses of the data obtained for the three strata revealed that the study area was homogeneous in relation to soil $\mathrm{pH}$ and particle size distribution (Figure 2), nevertheless are heterogeneous with respect to substrate organic matter content and electrical conductivity (Figure 3), two variables that are mutually dependent. Soil/ sediment containing high levels of organic matter and smaller inorganic particles (clay and silt) have greater cation exchange capacity or the ability to retain positively charged ions $(\mathrm{Ca}$, $\mathrm{Mg}, \mathrm{K}, \mathrm{Na}, \mathrm{NH}_{4}$, or $\mathrm{H}$ ) than soils with lower organic matter and clay/ silt content. The presence of these ions in the moisture-filled soil pores will enhance soil electrical conductivity (EC) in the same way that salinity does. Substrate close to the shoreline $(0-20 \mathrm{~m})$ at Kadolkele seagrass bed therefore is evident to be different from the rest of the area beyond $20 \mathrm{~m}$ from the mangrove belt at the shore, where relatively a high water level prevails.

Higher density of seagrasses in the area beyond $20 \mathrm{~m}$ from shoreline (Figure 4) however, would have contributed to its significantly high content of substrate organic matter and resultant higher EC. Among the factors that 
affect EC of soil/ sediment, porosity, salinity, water content and temperature of this relatively small $(30 \mathrm{~m} \times 30 \mathrm{~m})$ sampling area do not likely to show much variability, but the cation exchange capacity which depends on silt, clay and organic matter content of soil.

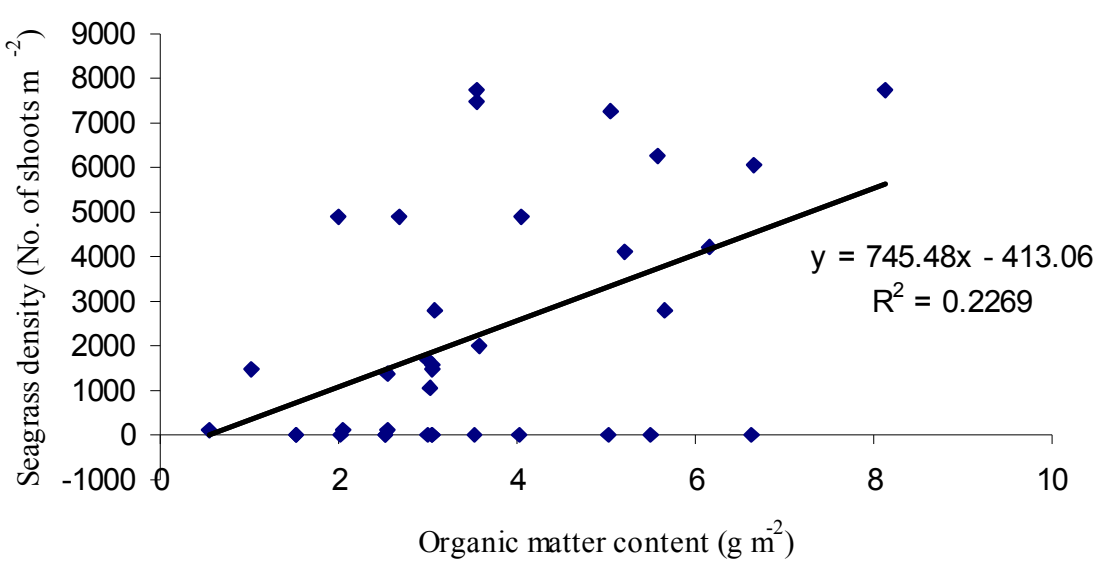

Figure 5: Relationship between organic matter content density of marine angiosperms at Kadolkelle

\section{Species richness}

Out of the seven seagrass species encountered from Sri Lankan marine and brackish waters (Jayasuriya 1991), only two species, i.e. Halodule pinifolia and Halophila ovalis were found to occur in the sampling area of the seagrass bed at Kadolkelle. $H$. pinifolia was the most abundant species which was found distributed up to $30 \mathrm{~m}$ from the shoreline and the area beyond. Although, Jayasuriya (1991) reported the presence ofHalophila beccari at Kadolkelle seagrass bed, it was not encountered within the study site which was $30 \mathrm{~m} \times 30 \mathrm{~m}$ in extent. This could be either due to the seasonal changes in physicochemical environment in the estuary that affect the occurrence of seagrass species (Amarasinghe et al.2003) or that $H$. beccari shows a patchy distribution in the area.

\section{Species evenness and diversity}

Low density (124 shoots $\mathrm{m}^{-2}$ ) of seagrasses in stratum 1 , which is composed only on $H$. pinifolia, is a noteworthy observation in this seagrass bed. It is appropriate to conclude that other habitat characteristics and conditions, more than the substrate, play an important role in determining the species richness at the shoreline. It may be the wave action at the shoreline that does not allow a stable substratum to occur and also sets in an environment where colonization is difficult and the mechanical damage to the delicate seagrass plants is high (Riis and Hawes 2003). On the contrary, stratum 3 represents an area of less water turbulence, due to the presence of relatively a high $(80-120 \mathrm{~cm})$ water level that will render comparatively a calm environment near the substratum where seagrasses occur. It is likely that 
high day time temperature, turbidity, low oxygen levels and human trampling that have not been monitored in the present study too may contribute, to varying extents, in resulting low marine angiosperm species richness and diversity at the shallow waters near the shoreline.



Figure 6. Relationship between abundance of $H$. pinifolia and organic matter content of the substrate at Kadolkelle

Presence of $H$. pinifolia in all three strata, although in low numbers in stratum 1, indicate its' ability to tolerate aquatic environmental conditions that prevail in all three strata. Since the substrate was homogenous in relation to $\mathrm{pH}$ and silt content, it could be deduced that absence of $H$. ovalis at the shoreline may have been caused due to the same variables mentioned previously for having low diversity in stratum 1. Apart from preventing the establishment of a stable substratum, constant churning due to waves at the waters' edge near the mangroves, particularly during the south west monsoon, may contribute to detachment of delicate $H$. ovalis leaves from their rhizomes and even complete removal of the plants from the substratum. On the contrary, $H$. pinifolia, that has thicker and longer ribbon-like leaves that form a tuft of leaves at each node, appears to resist well to high temperature and constant churning by tidal movement of water and windgenerated wave action at the shoreline.

Although species richness is similar in strata 2 and 3, highest density (Figure 4) was recorded for stratum 3. The highest diversity (0.074) was calculated for stratum 2 , and it is evident to have resulted from relatively high (0.231) in distribution of the two species. The aquatic environmental conditions, including substrate characteristics that prevail in stratum 2 can therefore deduced to be favourable for both the species. As such, highest ecological stability can be expected to be associated with stratum 2, or the area $10-20 \mathrm{~m}$ from shoreline. The Shannon-W einer diversity index value for the area close to the mangrove bordered shoreline (stratum 1) was zero (as the area was mono-specific), while it was greater in stratum 2, $(0.074)$ than in 
3 (0.054), indicating Kadolkele seagrass bed to be an area of low marine angiosperm diversity.

The higher organic matter content (Figures $5 \& 6$ ) could either be the consequence of the presence of seagrasses, particularly, $H$. pinifolia in high densities, or it could be deduced that the seagrass species would have preferably colonized these areas of high organic matter and silt. A similar trend has been observed in seagrass beds in north America (Raffaelli and Hawkins 1999) and it is attributed to the changes that seagrass communities bring about in local hydrodynamics that becomes conducive for settlement of suspended matter. Several structural characteristics of seagrasses, including level and arrangement of fibre, and water content, make it particularly amenable to mechanical and subsequent microbial degradation (Lanyon and Sanson 2006). Less fibre-containing seagrasses such as Halophila ovalis can be expected to break down at a faster rate than comparatively a high fibrecontaining seagrass such as $H$. pinifolia, thus contributing to the organic matter content of the substratum. Besides, the calm aquatic environment at stratum 3, compared to the stratum 1 at the shoreline may also contribute to sedimentation and settlement of organic matter on the estuarine bed thus resulting relatively high organic matter content in the substratum.

\section{Acknowledgement}

Authors gratefully appreciate the staff at the National Aquatic Resources Research and Development Agency's (NARA) Regional Research Station at Kadolkelle, for their assistance given in field data collection.

\section{References}

Abeywickrama, B.A. \& P. Arulgnanam, 1991.

The marine angiosperms of Sri Lanka. UNESCO: Man and the Biosphere National Committee for Sri Lnaka, Natural Resources, Energy \& Science Authority, Sri Lanka, Publ. No. 18: 1-38

Alphonse, A. \& Kirk O.Winemiller 1997.

Trophic ecology and ecomorphology of fish assemblages in coastal lakes of Benin, West Africa. Journal of Eco-science 4:6-23.

Al-rousan, S. A., M. Y. Rasheed, M. A. Khalaf \& M. I. Badran , 2005.

Ecological and geochemical characteristics of bottom habitats at the northern Jordanian coast of the Gulf of Aqaba. Chemistry and Ecology, 21(4): 227-239

Amarasinghe, M.D., Thenuwara, R., Fernanado, S.S. and

Pahalawattaaracchchi, V ., 2003.

Species richness and biomass distribution of marine angiosperms in

Negombo lagoon. Proc. Sri Lanka Asso. Adva. Sci. Colombo : 16

Arber, A., 1920. 
Water Plants, a Study of Aquatic Angiosperms. Cambridge University Press, $436 \mathrm{pp}$.

Brower, J. E, J.H. Zar \& C.N. von Ende 1997.

Field and Laboratory Methods for General Ecology. McGraw-Hill Co., USA

Dayaratne, P., M. W. R. N. De Silva and L. Olof 1997.

The Puttalam/Mundel estuarine system and associated coastal waters. NARA, Colombo, Sri Lanka

Den Hartog, C. 1970.

The Seagrasses of the World. North Holland Publishing Company, London.

De Silva, M.W.R.N. \& R.A.S. Ranatunga, 1987.

Seagrass beds of Negombo lagoon. National Aquatic Resources Agency, Colombo

Duarte, C.M., 1991.

Allometric scaling of seagrass form and productivity. Marine Ecology Progress Series. 77: 2899-300

Dumbaald, B.R. \& S. Wyllie 2003.

The influence of burrowing Thalassinid shrimps on the distribution of intertidal seagrasses in Willapa Bay,Washinton,USA. Aquatic Botany. 77:27-42.

Eigenberg R.A., J.W. Doran, J.A. Nienaber, R. B. Ferguson \& B.L. Woodbury 2002.

Electrical conductivity monitoring of soil and available $\mathrm{N}$ with animal manure and a cover crop. Journal of Agriculture Ecosystem and Environment. 88:183-193.

Fonseca, M.S., 1989.

Sediment stabilization by Halophila decipience in comparison to other seagrasses. . Journal of Estuarine, Costal and Shelf Science. 29:501-507.

Fourqurean, J.W ., A. Willsie, C.D. Rose and L.M. Rutten. 2001.

Spatial and temporal pattern in seagrass community composition and productivity in south Florida. Marine Biology 138:341-354.

Gamp, M.C., I. Brigitta \& A. Brearley 2003.

Mesofaunal borers in seagrass world-wide occurance and a new record of boaring polychaetes in the Mexican Caribbean. Journal of Aquatic Botany.76:65-77.

Jayasuriya, P.M.A. 1991.

The species composition, abundance and the distribution of seagrass communities in Puttalam lagoon. Journal of Vidyodaya Sci. 3:93-102 Johnson, P. \& R. Johnston 1995.

Productivity and nutrient dynamics of tropical seagrass communities in Puttalam lagoon, Sri Lanka. Ambio 24 (7-8): 411-417

Lanyon, J. M. \& G. D. Sanson, 2006. 
Mechanical disruption of seagrass in the digestive tract of the dugong. Journal of Zoology.270 (2): 277-289

Odum, P., 1994.

Fundamentals of Ecology. Sounders College Publishers. Philadelphia.

Raffaelli, D \& S. Hawkins, 1999

Intertidal Ecology. Kluwer Academic Publishers, Dordrecht, The Netherlands: 130

Ravikumar, K. \& R. Ganesan, 1990.

A new subspecies of Halodule ovalis (R.Br.) J.D.Hook.(Hydrocharitaceae) from the Eastern Coast of Peninsular India. Journal of Aquatic Botany 6:351-358.

Riis, T. \& I. Hawes, 2003.

Effect of wave exposure on vegetation abundance, richness and depth distribution of shallow water plants in a New Zealand lake. Freshwater Biology. 48:75-87

Samarakoon, J. \& van Zon, H. (eds.) 1991.

Envirnmental profile of Muthurajawela and Negombo lagoon.

Greater Colombo Economic Commission, Sri Lanka, Euroconsults, The Netherlands. $171 \mathrm{p}$

Takhtajan, A. 1969.

Flowering Plants, Origin and Dispersal. Smithsonian Institution

Press, Washington.

310 pp.

Walker, D. L. \& McComb. 1990.

Salinity Response of the seagrass, Amphibolis antractica (Labill.) Sonder et Aschers.: An experimental validation of field results. Journal of Aquatic Botany, 36:359-366. 